\title{
Role of Family-Business in Women Empowerment
}

\author{
Sowjanya S. Shetty. $M^{1}$ and V. Basil Hans ${ }^{2}$ \\ ${ }^{1}$ Lecturer in Economics, Poornaprajna College, Udupi, Karnataka, India \\ ${ }^{2}$ Associate Professor \& HOD of Economics, St. Aloysius Evening College, Mangalore, Karnataka, India \\ E-Mail: sowjanya936@gmail.com,vhans2011@gmail.com
}

\begin{abstract}
Family is central to the founding of society and society completes nation. Family enterprise is an influential element in commencing and nourishing socio-economic development. Family enterprise has been active around the world for centuries and also accounts for a large share of economic activity in the contemporary period. No nation, society and family can bourgeon and be prosperous if women, who represent half of the human force, are not treated equally. In many parts of India, the participation of women in decision making is inexcusably low, and they are marginalized and play a secondary role. Gender equality and women empowerment are essential for the development and wellbeing of family, society and to a nation. Gender inequality in India is because of the existence of the patriarchal structure of the family system. Empowerment of women must be accomplished at all levels to enable them to make decisions about themselves and also family matters. Education is believed to be one of the most fundamental components of Empowerment. Education enables women to have an analytical and scientific approach and recognize the realities around them. This paper is an attempt to discuss the role of family business in the empowerment of women, identifying the role of education as a reliable energy booster for the development and empowerment of women in a developing country like India.
\end{abstract}

Keywords: Education, Empowerment, Family Business, Gender Inequality, Women Entrepreneurs

\section{INTRODUCTION}

Business plays a pivotal role in providing access to goods and services that help women improve their living standards as well as to increase their mobility and potential. Companies' product design and development teams should consider how their goods, services, and technologies can offer both benefits and risks to women. Women touch every aspect of the business. For example, they are influential consumers of goods and services. A Goldman Sachs study shows that when women's spending and decision-making power increases, they affect consumer trends, such as household spending for the welfare of the family, which has implications for things like apparel, childcare, consumer durables, education, financial services, food, and healthcare sectors.

In the workforce, the advancement of women is also crucial to business success. Companies with women in leadership outperform their competitors, with a McKinsey study finding a 55 per cent increase in average company earnings before interest and tax. As businesses begin to priorities women's empowerment, they should be careful not to make it a "niche" issue that only the sustainability team or executive leadership addresses.

Defining corporate priorities for women's empowerment requires a strategic approach that weighs both existing initiatives and company priorities. One right place to start is the Women's Empowerment Principle. Once a company identifies women's empowerment as a priority and integrates women's empowerment into core business activities, the next step is to build strategic partnerships with donors and other stakeholders. Partnerships that harness the strengths of both business and the public sector are crucial to ensuring that economic progress in developing countries is linked to individual prosperity, gender equality, and shared opportunity (Pruzan-Jorgensen \& Shields, 2015). The era of globalization has enhanced the role of women entrepreneurs. However, India may fail to obtain benefits without the participation of women, who form a significant mass of society. Active participation of women in economic activity and decision making is very much needed to increase the GDP growth (Hans \& Sowjanya, n.d.), Recognition, reputation, resource regeneration are some of the advantages of women entrepreneurship besides monetary gains and financial inclusion (Colaco \& Hans, 2018).

The family is one of the hoariest persisting social institutions and also a fundamental element of Indian society. A family is regarded as a central element of Indian society. Women who are given secondary status have gradually transitioned to subjugate an essential role not onlyin the family but in the family business also. Women frame a necessary human capital for enhancing the economic power of a nation. The development of any nation is not feasible when half of its population is marginalised. Gender equality and women empowerment are one of the prime priorities of sustainable development goals. Women play a crucial role in the process of globalisation. The literacy rate of women is around 50 percent in almost all developing countries. In India, women represent half of the population and play a significant role in economic activity, and her role is increasing in globalised India.

Women are mostly acclaimed and found fathomless; however, they are often unseen in the development picture. Refusal of opportunities initiates from home and continues afar to other institutions of learning and also to the workplace. Differences in avenues to growth and 
development thus become issues of concern not just for women, but for the entire society and nation as a whole. Family businesses, as a group, have virtually been neglected in research on women in the family business until today in the Indian context. This stands in sharp contrast to the relevance of family businesses to overall economic activity and the importance of women in family businesses.

\section{PURPOSE AND PLAN OF THE STUDY}

The study is planned, and it proceeds in the following way:

\section{A. Objectives of the Study}

1. To examine the role of family business in developing women entrepreneurship and empowerment

2. To study the problems faced by women entrepreneurs

3. To analyse the initiatives of the government in promoting women entrepreneurs

\section{B. Methodology}

The present study is based on the collection of data from secondary sources. Secondary data are obtained from various published and unpublished records, books, magazines and journals, both print and online.

\section{Conceptual and Operational Framework}

In India involvement of women in economic activity is familiar from several decades. The role of women has departed through numerous transitions. It took centuries for women's role in shifting to the present path. Traditionally employment of women was restrained to domestic errands and familial work. With the increase in the population and economic compulsion necessitated women's involvement in the labour market. The process of liberalisation, privatisation and globalisation brought changes in the sociocultural attitudes towards women's education and women's employment. Women were measured as proficient, assertive, confident and skilled. In modern days Indian women have acquired high self-esteem, expertise in all fields and are potential of solving the problems independently.

Women's increased control over household resources may increase women's welfare by fortifying their bargaining position within the household, but $\mathrm{t}$ ample empirical evidence on collective models suggests that women in developing countries generally receive fewer productive resources within households and therefore have less bargaining power (Mammen \&Paxson, 2000).

\section{Entrepreneurship and Family Business}

Entrepreneurship and family businesses are considered as the most relevant topics for managerial practice and academic inquiry over the past decade. The distinctiveness of family business is related to the involvement of the family in the business, specifically in its ownership and leadership/management of the business. Family business issues impact the ownership, leadership and management of the overall business. Family businesses may be distinct from the nonfamily businesses, and the dynamics can also be assumed to be affected by the specific characteristics of family businesses, setting them apart from nonfamily businesses.

\section{Empowerment}

Corsun and Enz (1999) defined empowerment as a motivational process of a person's inherent experience of feeling empowered which is associated with entrusting power to exercise personal decision on one's own life. Empowerment as a multi-dimensional process should enable the individuals to realise their identity-powers and recognition-resources in all spheres of life. It consists of greater access to knowledge and opportunity, greater autonomy in making decisions or freedom from the shackles imposed on them by custom, belief and practices in the society (Radhakrishnan, 2013). G Sen (1993) defines empowerment as "altering relations of power....which constraint women's options and autonomy and advocacy affect health and wellbeing". Kabeer (2001) offers a practical definition that is "The expansion in people's ability to make strategic life choice in a context where this ability was previously denied to them".

\section{LITERATURE REVIEW}

Women are natural entrepreneurs. They have inherent qualities that guide them to success in business activities such as willingness to learn new skills and enhance knowledge, ability to adapt to new situations and manage conflicts, sensitivity, will power etc. They are considered to be good at the balancing act and seeing the larger picture without overlooking essential details. They are generally considered to be hardworking and diligent in their work. They can lead as well as work behind the scenes as team players (Gambhir 2013).

Anna (1990) in her study in Kerala identified that bettereducated women were more enterprising than their counterparts. A similar study was also conducted by Arthur, Richard, Kishore and Hesan (1993) to study the effects of education on business ownership and found likelihood increased with increasing levels of education. This finding supports the notion that less educated women may face financial, human capital constraints which limit their business pursuits. Education creates conscious in women about existing rights encourages women to explore their hidden entrepreneurial perspective, intensifying awareness also exploring newer avenues were motivates them to take an active part in business to enhance economic and social status.

Rowe and Hong (2000), in their study on wives in the family business, also focused on the likelihood factors of a wife's participation in a family business. Their main conclusion was that wives are more likely to be involved 
when the business was bought, invested or started by the couple, than when the business was inherited or given. To complement this Maas and Diederichs (2007) have provided useful insight into husband-wife teams as the foundation and base of family businesses

\section{HISTORY OF WOMEN BUSINESS PERSONS}

Throughout world history, except for recent times, society has been exclusively masculine-oriented. Men had the exclusive right to occupy both leading and ordinary positions in politics, economy, social and cultural life. Women were supposed to be housewives and mothers, staying at home and looking after their children. It was absolutely out of the question for a woman to have her say in any serious matter. Females were oppressed and humiliated until the 20th century.

There are numerous examples of women successfully starting and running businesses, particularly family-owned ones. At the end of the 20th century, the research was conducted in order to determine the oldest family business in the world. Surprisingly, it found nearly a hundred famous family businesses. Take a look at the following list of some of the world's oldest companies:

1. Kongo Gumi (Japan, building and repairing Buddhist temples);

2. Hoshi Ryokan (Japan, hotel business);

3. Château de Goulaine (France, owning a castle with a butterfly collection, museum, and vineyard);

4. Barone Ricasoli (Italy, producing wine and olive oil);

5. Barovier \& Toso (Italy, glassmaking);

6. Hotel Pilgrim Haus (Germany, hotel business);

7. Antinori (Italy, wine production);

8. Berenberg Bank (Germany, owning a private bank);

9. Eduard Meier (Germany, shoe company);

10. James Lock \& Co. (the UK, production of hats);

11. Yamamotoyama (Japan, the world's oldest familyowned tea company);

12. Farina Gegenüber (Germany, the oldest perfume company in the world);

13. Tissages Denantes (France, cloth production);

14. Hacienda Los Lingues (Chile, ranch business).

Each of the companies listed above has been existing for more than two centuries and was family-owned throughout its existence. Family businesses acted as suitable platforms for women to practice their entrepreneurial skills, which with time has led to the feminist revolution. Succeeding in family businesses first, women then attempted to break free from discrimination, trying themselves in setting up their own companies. Female-run business was considered to be "shameful"; nevertheless, in as early as the 18th century the following businesswomen were distinguished:

1. Eliza Lucas Pinckney (agricultural work: running the plantations, planting indigo seeds; resulted in a successful family business);

2. Mary Katherine Goddard (newspaper publisher).
The next century brought even more female entrepreneurs:

1. Mary Gage (initiator of the USA stock exchange for women, aimed at investing in railroads);

2. Rebecca Pennock Lukens (director of the inherited iron and steel company);

3. Biddy Mason (the first black female real estate owner);

4. Catherine Anselm Gleason (mechanical engineer, the first female president of the First National Bank of Rochester, member of the American Concrete Institute, member of the American Society of Mechanical Engineers).

The feminism boom started in the 20th century, bringing noticeable changes in the workforce sphere. Moreover, women were even endued with the right to vote. That was a real success, resulting in more and more women getting engaged in business:

1. Madam CJ Walker (one of the first female millionaires, cosmetics business);

2. Elizabeth Arden (initiator of the international beauty business);

3. Mary Kay Ash (owner of the direct sales cosmetics company);

4. Olive Ann Beech (one of the owners of the aircraft company serving the US military);

5. Katherine Meyer Graham (director of The Washington Post).

One of the opportunities for women to show their work potential was World War II, which increased the number of female workers by $10 \%$ during five years of wartime. Women obtained highly responsible positions, working on more or less equal working conditions with men in order to substitute the lack of male workers engaged in military operations.

Later on, together with social alternations and increasing divorce rates, women were getting involved in business even more. They had no financial support, and, consequently, occupied a considerable niche in a labour market, starting up their entrepreneurship.

A significant step forward was done in 1988 when the US Congress issued the Women's Business Ownership Act. It removed the former necessity for married women to get their husbands' signature while signing business-related papers. Also, the Act enabled women to get bank loans without the written approval of their husbands. Such a document, approved on the state level, became the first step to setting the equality of men and women in the business sphere.

Nowadays, the situation has improved to such an extent that half of all the workers in the world are females. They occupy the positions of managers, CEOs, governors, which was impossible even in the previous century. Things are changing super-quickly! 
According to the Credit Suisse Global Family, there are over 900 large companies in the world nowadays that are family-owned, with women occupying the executive positions. Among such world known business giants there are the following:

1. Samsung Electronics (South Korea);

2. Facebook (USA);

3. Oracle (USA);

4. Walmart (USA).

In the 21 st century, female entrepreneurship rate increased by 54 per cent, and the number of women-governed companies increased by 45 per cent. At present, there are nearly 11.3 million businesses run by women in the USA alone. As a result, the economy gets improved, bringing considerable revenues of almost $\$ 2$ trillion. Social researches prove that women are three times more likely to start their businesses than men. This statistics is quite promising. (Writ Ology, 2017)

\section{WOMEN ENTREPRENEURSHIP IN INDIA}

Entrepreneurial initiative among women spurs them to develop inner freedom which subsequently makes them feel empowered. Women are coming in the forefront and participating in family business with full enthusiasm and zeal. The reason for joining in the business could vary from the interest, need, circumstances etc. However, it is leading to a good and welcome change in society (Dusseja 2017).

Women always played an active role in economic activity either directly or indirectly. Most of the family businesses are erected on the sacrifice and support of women be it grandmothers, mothers, sisters, wife, or daughters.

A. Indian Women Business Leaders: There are many Indian Women (some even mothers) who are shining examples in family business. A few are

1. Roshni Nadar Malhotra (HCL)

2. Sulajja Firodia Motwani (Kinetic Motor Company Limited)

3. Vinita Gupta (Lupin Pharma)

4. Ashni Biyani (Big Bazaar)

5. Meher Pudumjee (Thermax Group)

6. Nandini Piramal (Piramal Enterprises)

7. Nisaba Godrej (Godrej Consumer Products Ltd)

8. Tanya Dubash (Godrej group)

9. The Reddy sisters - Preetha, Sangita, Sunita and Shobhana (Apollo Hospital)

\section{PROBLEMS AND INITIATIVES}

Most of the women entrepreneurs are not treated on par with men. The extension in gender disparity results in the form of various hurdles for women entrepreneurship. They are subjugated at different levels. Some of the problems faced by the women in business include:
1. Gender inequality-Male subjugated patriarchal society

2. Monetary constraints- lack of access to financial resources

3. Severe competitions from structured industries and male counterpart

4. Seclusion to information- regarding opportunities available for women entrepreneurs

5. Family errands- Early marriages, lack of support, conflicts

6. Stumpy mobility- safety issue

7. Lack of access to training- limited access to getting trained, erudition to new skills

8. Socio-cultural barriers

9. Lesser access to education

10. Abhorrence to take risks

A. Role of Education: Education enables the weaker sections to transform their life for the better. Education has acquired a place of prominence in the development plan of India. India has toiled to boost its literacy rate from just about $18 \%$ in 1951 to $74 \%$ in 2011 (GOI 2011). Education is one of the essential rudiments for women's economic empowerment. Educated women are more dynamic at home, well paid in the workplace and further able to partake in social economic and political decision making. Education is the key to unlock all sorts of tribulations, yet the most significant gender gap both in terms of enrolment and educational attainment which results in low educational accomplishment. As education is an input of human development, educational equity will facilitate entrepreneurial development.

B. Government Initiatives: Development of women has been a policy objective of the government since Independence to date. The Government of India has more than 27 schemes for women operated by different departments and ministries.

Some of these are: Entrepreneurial Development programme, Women's Development Corporations, Trade Related Entrepreneurship Assistance and Development, Working Women's Forum, Indira Mahila Yojana, Indira Mahila Kendra, Mahila Samiti Yojana, Mahila Vikas Nidhi, Micro Credit Scheme, Rashtriya Mahila Kosh, SIDBIs Mahila Udyam Nidhi, Mahila Vikas Nidhi, SBI's Stree Shakti Scheme, NGOs Credit Schemes, Micro \& Small Enterprises Cluster Development Programmes, Rajiv Gandhi Mahila Vikas Pariyojana, Priyadarshini-Project - A programme for Rural Women Empowerment and Livelihood in Mid Gangetic Plains, Trade Related Entrepreneurship Assistance and Development Scheme for Women, MUDRA and so on.

The efforts of government and its different agencies are ably supplemented by Micro Finance Institutions and NGOs that are playing an equally significant role in enabling women empowerment. 


\section{SUGGESTIONS}

It is necessary to make marginalised groups employable by making education up to the secondary level universal so that they can later acquire higher education or skill training. This will help them to be employed in better-paid jobs in the formal sector. Some of the standard measures essential to empower women entrepreneurs are as follows:

1. Easy access to finance at concessional rate must be provided to initiate women entrepreneurship

2. Endorsing women's participation in all walks of life

3. Nurturing the role of women in the decision-making process

4. Changing the role of women from homemakers to managers

5. Creating consciousness among women about the various opportunity of business enterprises

6. Developing standards of education and regulating vocational training programmes facilitating women to surpass in the decision-making process and increasing entrepreneurial ability.

7. Solidification of partnership with women's organisations

8. Facilitate interaction with other women entrepreneurs.

9. Women should be allowed to enter professional careers in all the fields, enabling women employment across industries

10. Eliminate discrimination between men and women by changing orthodox, traditional and conservative attitudes of the people towards women entrepreneurs

11. Promoting the Formation of a cooperative association of women entrepreneurs to mobilise resources and ideas to help other women entrepreneurs.

\section{CONCLUSION}

The participation of women in the field of entrepreneurship is increasing at a considerable rate. There is an imperative need to enlarge women's economic status as they outline essential to the course of economic development of any economy. Education is regarded as a critical landmark of women empowerment as it enables them to face the challenges, to confront their traditional role and change their life. According to the World Bank's 2012 World Development Report: Gender Equality and Development, closing these gender gaps matters for development and policy making. Greater gender equality can enhance economic productivity, improve development outcomes for the next generation, and make institutions and policies more representative. Many gender disparities remain even as countries develop, which calls for sustained and focused public action. Corrective policies will yield substantial development payoffs if they focus on persistent gender inequalities that matter most for welfare. To be effective, these measures must target the root causes of inequality without ignoring the domestic political economy.

\section{REFERENCES}

[1] Revenga Ana \& Shetty, Sudhir (2012) Empowering Women in Smart Economies.Finance and Development, 49(1). Retrieved from https://www.imf.org/external/pubs/ft/fandd/2012/03/revenga.htm

[2] Anna, V. (1990). Socio-Economic Bias of Women Entrepreneurship.SEDME- Small Enterprises Development, Management \& Extension Journal 17(1), 17-31.

[3] Dolinsky, Arthur, Caputo, Richard K, Pasumarthy, Kishore \& Quazi Hesan (1993). The Effects of Education on Business Ownership: A Longitudinal study of women. Entrepreneurship Theory and Practice1, 8(1), 43-48.

[4] Colaco, Vembly \& Hans, V. Basil (2018). Redefining Entrepreneurship in India - Women As Their Own Bosses. Retrieved from https://papers.ssrn.com/sol3/papers.cfm?abstract_id=3266062

[5] Corsun, D. L., \& Enz, C. A. (1999). Predicting psychological empowerment among service workers: The effect of support-based relationships. Human relations, 52(2), 205-224. Retrieved from Cornell University, School of Hotel Administration. Retrieved from http://scholarship.sha.cornell.edu/articles/615

[6] Danjuma, Safiya K, Muhammad, Yusuf A, \& Alkali, Larai F. (2013). Factors Militating Against Women Economic Empowerment and Poverty Reduction In African Countries. IOSR Journal of Business and Management, 13(6), 47-51.

[7] Dusseja, A. (2017). A Critical Review of Role of Women in Family Business. International Journal of Management and Applied Science, $3(1), 126-127$

[8] GOI (2011).Census 2011: Office of the Register General and census commissioner, Ministry of Home Affairs, Government of India.

[9] Gambhir. D. (2013). Women \& Business in India. IRACST International Journal of Commerce, Business and Management, 2(5), 228- 232 .

[10] Hans. V. Basil \&. Shetty. Sowjanya. S. M (n.d.). Women Entrepreneurs in India: Approaches to Education and Empowerment. Al-Shodhana, forthcoming

[11] Kabeer, Naila. (2001). Reflecting on the Measurement of Women's Empowerment, In Discussing Women's Empowerment-Theory and Practice. Sida Studies, No 3. NaumGrafiskar A B, Stockholm.

[12] Mammen, K \& Paxson, C. (2000). Women's work and economic development, Journal of Economic Perspectives, 14(4), 141-164.

[13] Maas, G. and Diederichs, A. (2007). Manage family in your family business, Northcliff, South Africa: Frontrunner Publishing (Pvt) Ltd.

[14] Mehta Balwant Singh \& Shree Megha (2017), Inequality, Gender and Socio-Religious Groups. Economic \& Political Weekly 52(8), 56-60.

[15] Pruzan-Jorgensen; Peder Michael\& Shileds Lauren (2015).The Role of Business in Advancing Women's Empowerment. Blog. Retrieved from https://www.bsr.org/en/our-insights/blog-view/the-role-ofbusiness-in-advancing-women's-empowerment

[16] Radhakrishnan, N. (2013). Women Empowerment in India Emerging Issues, Southern Economist, 52(4), 15-18.

[17] Rowe, Barbara R; Hong, Gong-Soog (2000). The Role of Wives in Family Businesses: The Paid and Unpaid Work of Women. Family Business Review 13(1), 1-13.

[18] Sen, Gita. 1993. Women's Empowerment and Human Rights: The Challenges to Policy. Paper presented in the Population Summit of the World's Scientific Academies.

[19] World Bank. Human Development Report 2016. UNDP.

[20] Writ Ology (2017 October 12). Women in Family Business. Retrieved from https://writology.com/blog/women-in-familybusiness.html 